\title{
Comparative characteristics of export transactions of a chemical industry enterprise
}

\author{
Tatyana Kirillova ${ }^{1, *}$, Svetlana Golovkina ${ }^{1}$, Maria Kupriyanova $^{1}$, and Maria Azarova ${ }^{1}$ \\ ${ }^{1}$ Peter the Great St. Petersburg Polytechnic University, Saint Petersburg, Russian Federation
}

\begin{abstract}
In the work, the economic justification of the efficiency of export operations of LLC "Industrial Group "Phosphorite" was carried out. The enterprise under study is a part of EuroChem Group AG and sells products on the Russian market and also exports mineral fertilizers to foreign markets. The organization and features of export operations are investigated. The basic principles and methods of state regulation of foreign trade activity in the Russian Federation are considered. When considering the world and domestic market of mineral fertilizers, the analysis of volume indicators of chemical industry production was carried out, the main importing countries of Russian fertilizers and the main competitors of EuroChem Group AG were identified. The paper analyzes the foreign economic activity of EuroChem Group AG and its subsidiary LLC "Industrial Group "Phosphorite". The main markets for products were identified and a comparative assessment of the effectiveness of two export transactions was carried out. Based on the effectiveness assessment, recommendations were made to increase the profitability of export transactions. The implementation of measures to increase the efficiency of export transactions will lead to an increase in the company's profitability.
\end{abstract}

\section{Introduction}

International trade is a key tool for a manufacturing enterprise to improve its specialization, expand markets for products and increase production volumes.

Foreign economic activity plays an important role both for the country as a whole and for a single enterprise. This is a special area of economic activity, which is associated with international production and scientific-technical cooperation, import and export of finished products, as well as with the enterprise entering the foreign market.

Every large enterprise engaged in foreign trade needs to constantly improve its export operations. A manufacturing enterprise should develop strategies for entering new foreign sales markets and take actions to implement the developed strategy. Separate divisions of the enterprise directly related to foreign economic activity need to constantly monitor and analyze international transactions in order to identify and eliminate shortcomings in order to increase the efficiency of such operations and increase profits [1].

The relevance of this topic is determined by the development of globalization processes in the world and, as a consequence, the requirement for the development of foreign

* Corresponding author: kirillova tan@,rambler.ru 
economic activity of enterprises [2, 3]. For successful cooperation with foreign partners and profitable work, the enterprise needs to correctly evaluate the effectiveness of export operations and make the right management decisions.

Evaluation of effectiveness allows us to determine the expediency and effectiveness of foreign economic operations. Otherwise, there may be losses due to insufficient economic justification of export or import transactions.

\section{Methods}

The problem at the center of this study is the need to evaluate the effectiveness of export operations of companies. The research hypothesis formulated in accordance with the proposed research problem is that the efficiency of export transactions is influenced by a wide range of factors, the identification and optimization of which helps to increase the profitability of transactions, which, in turn, leads to an increase in the company's net profit.

The efficiency of export operations is usually expressed using the ratio of result to cost. The target orientation of such an attitude is the desire to maximize. In this case, the task is to maximize the result per unit of cost. Analysis of the effectiveness of export operations of a commercial organization allows you to:

- determine the stability of the development of export operations;

- characterize the effectiveness of the external economic activity of the organization in conditions of limited information (information vacuum);

- identify possible options for the dynamics of the effectiveness of the organization's foreign economic activity on the basis of the current and prospective structure of relations between the estimated indicators;

- explore the possible consequences of managerial decisions related to the dynamics and structure of the organization's foreign economic activity and foreign policy in terms of efficiency;

- analyze export costs, as well as take measures to reduce the cost of export operations.

To evaluate the effectiveness of foreign economic activity, profitability indicators can be calculated:

- transaction;

- sales;

- organization;

- assets;

- fixed capital;

- shareholders' equity.

Consider in more detail the profitability of the transaction. It is customary for enterprises to calculate two types of transaction profitability:

1. One-time profitability, which is calculated as the ratio of profit excluding reimbursed VAT to the contract value of export products, multiplied by $100 \%$ :

$$
\mathrm{Io}=(\mathrm{Po} / \mathrm{C})^{*} 100 \% \text {, }
$$

where Io - export transaction profitability indicator; Po - profit indicator from the sale of export products profit excluding reimbursed VAT; $\mathrm{C}$ - contract value of export products.

2. Conditional profitability, calculated as the ratio of income from the sale of export goods, taking into account the returned VAT to the contract value of the goods:

$$
\mathrm{Ic}=(\mathrm{Pc} / \mathrm{C}) * 100 \% \text {, }
$$


where Ic - export transaction profitability indicator; Pc — profit indicator from the sale of export products, taking into account reimbursed VAT; $\mathrm{C}$ - contract value of export products.

To analyze the effectiveness of the execution of an export transaction, the foreign trade lump sum profit of the export product is determined as the value of the contract value minus the cost of the export product and the costs of this transaction. According to the current regulatory accounting system, the overhead export costs of an export product represent the sum of the costs of its sale and delivery.

Analysis of the profitability of an export transaction involves the study of factors influencing its change, such factors are:

- volume of exports and imports of goods;

- costs of production and sale of exports;

- turnover of working capital;

- solvency of the organization.

Reducing the cost of production (circulation) helps to increase the level of profitability of manufactured and sold export products. Such a reduction is achieved through the introduction of efficient and low-cost equipment and modern technologies, the establishment of systematic control over the arising direct and indirect costs, as well as the improvement of export operations [4].

\section{Results}

As part of this work, the export transaction of the LLC "Industrial Group "Phosphorite", which manufactures and sells phosphorus-containing fertilizers to the domestic and foreign markets, with an enterprise located in Germany, was considered. Under the contracts, LLC "Industrial Group "Phosphorite" sold to the German company 2275 tons of ammophos at a price of 26 thousand rubles / ton, delivery was carried out under the terms of DAT [5].

Table 1. Evaluation of the economic efficiency of an export transaction with an enterprise in Germany.

\begin{tabular}{|c|c|c|}
\hline Indicators & Units & Value \\
\hline Volume of sales & thousand tons & 2275 \\
\hline Product price & thousand rubles /ton & 26 \\
\hline Cost of exported goods & thousand rubles & 59150 \\
\hline VAT paid to suppliers & thousand rubles & 9464 \\
\hline Export overhead & thousand rubles & 39600 \\
\hline VAT on export overhead & thousand rubles & 105360 \\
\hline Contract value & thousand rubles & 1435,0 \\
\hline Contract value & $\begin{array}{c}\text { dollars (exchange } \\
\text { rate of 73.42 rubles/ } \\
\text { euro.) }\end{array}$ & 6610 \\
\hline $\begin{array}{c}\text { One-time income from the } \\
\text { sale of exported goods }\end{array}$ & thousand rubles & 20034 \\
\hline $\begin{array}{c}\text { Contingent income from the } \\
\text { sale of export goods }\end{array}$ & thousand rubles & 11,2 \\
\hline $\begin{array}{c}\text { Profitability of the } \\
\text { transaction (one-time) }\end{array}$ & $\%$ & 33,9 \\
\hline $\begin{array}{c}\text { Profitability of the } \\
\text { transaction (conditional) }\end{array}$ & $\%$ & $\%$ \\
\hline
\end{tabular}

According to table 1, the following conclusions can be drawn: the contract value of the goods is 105360 thousand rubles. Overhead export costs account for about $67 \%$ of the value 
of exported goods, which is a lot. As for the profitability of the transaction, the lump sum is only $11.2 \%$, and the conditional one, calculated taking into account the refunded VAT, is $33.9 \%$. This deal has shown low efficiency. This is primarily due to geographical remoteness and the need for transit traffic through Estonia, since the rate is carried by the carrier by sea through the Estonian port of Sillamae. In this regard, the share of export overheads is $66 \%$ of the total transaction value. In addition, the small profitability of the transaction is explained by the smallest share among the supplies of products of LLC "Industrial Group "Phosphorite". This situation can be corrected by reducing export overhead costs.

At present, LLC "Industrial Group "Phosphorite" exports $80 \%$ of all products, of which about $25 \%$ is delivered by sea. Cargo delivery by sea is carried out from the Estonian port of Sillamae.

The port of Sillamae is the closest EU port to Russia. It is located in Estonia, $25 \mathrm{~km}$ from the border of the EU and Russia, and $45 \mathrm{~km}$ from the production of LLC "Industrial Group "Phosphorite". The capacities of this terminal allow transshipment of a wide variety of goods and goods in the direction of Europe, the USA, Russia, other CIS countries, Southeast Asia and all other countries of the world.

EuroChem Group AG has its own subsidiary in the port of Sillamae, namely the Eurochem Terminal Sillamae terminal, which transports liquid chemical products and diesel fuel. And since the assortment of the exported products of LLC "Industrial Group "Phosphorite" includes not only phosphoric acid, but also a range of phosphorus-containing fertilizers, for the transshipment of this type of fertilizer, the company resorts to using the services of someone else's terminal.

For the past 15 years, established cooperation has been maintained between the Estonian port and the Russian production of mineral fertilizers of LLC "Industrial Group "Phosphorite". But the use of the Estonian port as a center of distribution has recently been aggravated in the light of certain political events. In addition, the presence of the need for transit payments in Estonia, encourages the idea of transferring the distribution of the enterprise to a Russian port.

Consider the possible ports of Russia on the Baltic Sea, where EuroChem can build its own terminal for transshipment and storage of fertilizers for further export. In figure 1, we consider the location of ports located on the Baltic Sea.

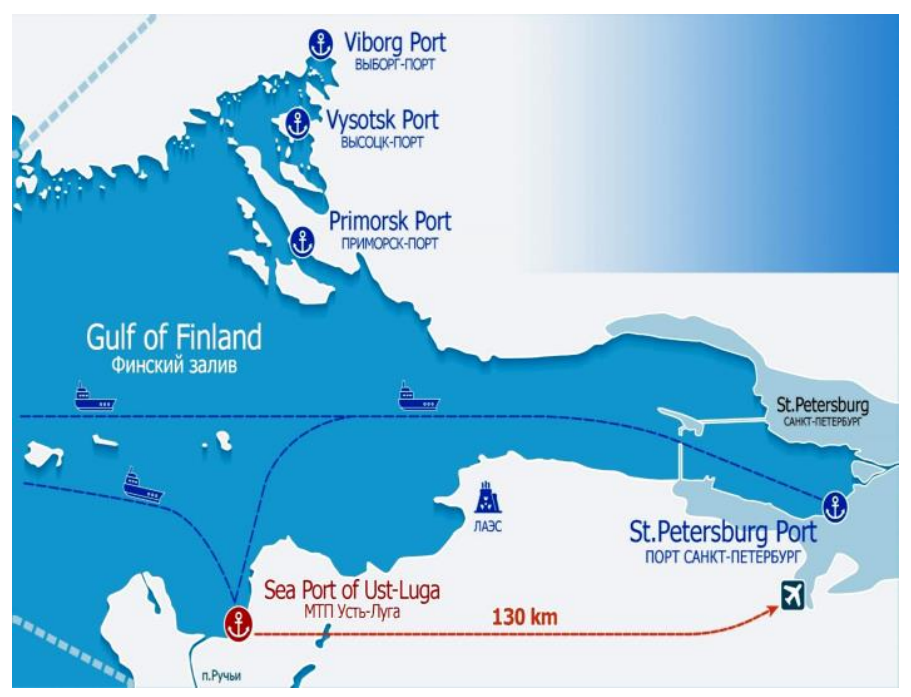

Fig. 1. Geography of the location of ports on the Baltic Sea. 
Let us consider in more detail the features of each of the ports of the Baltic basin presented in Figure 1.

1. The port of Vyborg.

Vyborg port is located in the Leningrad region in the city of Vyborg. The bay freezes in winter, but navigation is carried out year-round. There are 13 berths in the port, but berths No. 5, 11 and 12 are currently under reconstruction by the decision of FSUE "Rosmorport". This port has a cargo and passenger checkpoint across the border of the Russian Federation. All cargo is delivered to the port by road, sea, and the railway is also suitable for the port, which allows delivering goods to the berths.

Vyborg port has a specialized complex for transshipment of mineral fertilizers in bulk with a carrying capacity of up to 500 thousand tons per year, which goes to berth No. 10 .

The port of Vyborg is a small cargo port with a cargo turnover of 1931 thousand tons in 2018 [6].

Vyborg port is not attractive for LLC "Industrial Group "Phosphorite", which is explained by the outdated infrastructure of the port, the small depth of access routes, the lack of development opportunities, due to the fact that the port is supported by shipbuilding delivery and is located in the city of Vyborg, as well as strong remoteness from the production of LLC "Industrial Group "Phosphorite".

2. The large port of St. Petersburg.

The large port of St. Petersburg is the largest port in the North-West of Russia, which is located in the eastern part of the Gulf of Finland on the islands of the Neva River Delta. This port includes 4 cargo regions, sea and river passenger stations, as well as the berths of Kronstadt, Lomonosov, Gorskaya and Bronka. Large port terminals handle containers, automobiles and machinery, metal and pipes, heavyweights and long meters, timber, coal, grain and many other cargoes. In total, in the territory of the port of St. Petersburg, and this is 200 berths, with a total length of more than 150 kilometers, 28 stevedoring companies are engaged in cargo operations. The technical equipment of the companies allows them to service vessels with a displacement of up to 40 thousand tons and a draft of up to $11 \mathrm{~m}$.

The developed port infrastructure includes railway and crane tracks, roads, engineering networks, repair bases, fuel filling stations, treatment facilities. All the service staff has many years of experience in the development of technological maps and the manufacture of special devices for handling non-standard cargo [7].

The port in question is very busy with various terminals and stevedoring companies; a large number of cargo and passenger ships depart through the waters of the Gulf of Finland. And as a result, LLC "Industrial Group "Phosphorite" does not recommend choosing this port for the construction of its own terminal for transshipment of mineral fertilizers.

\section{Port Ust-Luga}

The sea trading port of Ust-Luga is located in the Luga Bay of the Gulf of Finland, on the territory of the Kingi-seppsky district of the Leningrad Region. In addition, the distance from the port to the state border of the Russian Federation is about $75 \mathrm{~km}$.

The port of Ust-Luga plays an important role in the organization of transit cargo transportation within the European transport infrastructure. The terminals and factory complexes that make up their structure transship and recycle more than 20 categories of cargo. Thanks to the use of modern technologies and equipment, the terminals are able to withstand the competitive terms of service.

Ust-Luga port has been operating only since 2001, but is already one of the 5 largest Russian ports located on the Baltic Sea. One of the main advantages of this port is that it bypasses the transport hub in St. Petersburg, which is very congested. At the moment, the project for the reconstruction of the Mga - Gatchina - Weimarn - Ivangorod railway section under the Ministry of Transport of the Russian Federation and OJSC "Russian Railways" is being completed. This project involves the first - the reconstruction of sections of the 
railroad on the approaches to the port, and the second - the construction of the Ust-Luga railway junction. The implementation of this project will reduce the cost of processing one wagon by $5 \%$, the energy intensity of technological processes at the station by $25 \%$ and in the growth of labor productivity by $20 \%$.

The next advantage of the port in question is the availability of free space for further development. Due to the reserve territories, the port of Ust-Luga can develop both in the northern region (Soikinsky Peninsula) and in the southern one - in the territory adjacent to the OJSC "Ust-Luga Container Terminal" [8].

The ideal port for sending your products is the port of Ust-Luga. Firstly, this port is a new dynamically developing one and has a huge amount of free space for the construction of its own transshipment terminal. Secondly, the port is only $50 \mathrm{~km}$ from the production of LLC "Industrial Group "Phosphorite". In addition, the construction of its own terminal for transshipment of mineral fertilizers includes the construction of its berths and the commissioning of warehouses for storing fertilizers. Such a terminal will allow transshipment and storage of not only the products of LLC "Industrial Group "Phosphorite", but also of such subsidiary EuroChem companies as Novomoskovsky nitrogen and the EuroChem-Usolsky potash plant under construction.

Having examined the three ports of the Leningrad Region and the current Estonian port of Sillamae used by LLC "Industrial Group "Phosphorite", one can say that the port of UstLuga should be considered the most promising for transshipment and sale of the company's products.

In table 2, we carry out a comparative description of transactions through the port of Sillamae, which is currently used to send goods to LLC "Industrial Group "Phosphorite", and the port of Ust-Luga, through which it is recommended to transfer the sale of enterprise products.

Table 2. Comparative characteristics of export transactions through the port of Sillamae and the port of Ust-Luga [9, 1011$]$.

\begin{tabular}{|c|c|c|}
\hline Export Transaction Indicators & $\begin{array}{c}\text { Port of } \\
\text { Sillamae }\end{array}$ & Port of Ust-Luga \\
\hline $\begin{array}{c}\text { Remoteness from the production of LLC } \\
\text { "Industrial Group "Phosphorite", km }\end{array}$ & 50 & 60 \\
\hline $\begin{array}{c}\text { Freight charge for 1 loaded wagon (65 } \\
\text { tons), rubles / wagon }\end{array}$ & 13540 & 1507 \\
\hline $\begin{array}{c}\text { Carriage charge for 1 empty wagon, } \\
\text { rubles / wagon }\end{array}$ & 1740 & - \\
\hline $\begin{array}{c}\text { Freight charges for the carriage of goods } \\
\text { by transit railways, rubles / ton }\end{array}$ & 237 & - \\
\hline $\begin{array}{c}\text { Freight charges for the transportation of } \\
\text { empty cars on transit railways, rubles / } \\
\text { wagon }\end{array}$ & 1600 & - \\
\hline Customs inspection fee, rubles / wagon & 512 & 3 \\
\hline Time spent on delivery to the port, hours & 8 & 1 \\
\hline The number of customs clearances, times & 2 & 1 \\
\hline Customs clearance time, days & 2 & 3 \\
\hline Route turnaround time, days & 5 & \\
\hline
\end{tabular}

Table 2 summarizes the key differences in the cost of shipping the products of LLC "Industrial Group "Phosphorite" to the Estonian port of Sillamae and the Russian port of Ust-Luga. The company's production is located approximately equal to the distance from the selected ports, the difference is only $10 \mathrm{~km}$ in favor of the port of Sillamae. Accordingly, the freight charge for delivering cargo to the port of Sillamae is less than 2140 
rubles per wagon to the port of Ust-Luga and amounts to 13540 rubles / wagon. But, despite this, conducting export transactions through the port of Ust-Luga is much more profitable, which is manifested in the following:

1. The key positive point for export shipments through the port of Ust-Luga is the absence of transit fees. And since transit is a significant price component of the logistic process of transporting goods from the manufacturer to the consumer, LLC "Industrial Group "Phosphorite" should avoid such large costs. So, for example, during transit via Estonian railways, the above-described enterprise must pay 237 rubles for each transported ton.

2. As you know, after cargo is delivered to the port and unloaded, the rolling stock is returned empty to production. Tariff rates for empty wagons on the railways of Russia and Estonia differ. In this regard, the return of 1 wagon from Sillamae will cost the company 1740 rubles / wagon, from Ust-Luga 1500 rubles / wagon. In addition, it should be noted that the return of an empty wagon from Estonia is carried out by a transit road, respectively, for such transportation it is necessary to pay transit in the amount of 1700 rubles / wagon.

3. When a cargo crosses the state border of the Russian Federation, customs authorities carry out customs clearance. Earlier, namely, until September 4, 2018, customs duties on the export of goods were levied on the basis of the customs value of goods. But since the entry into force of Federal Law No. 289 "On Customs Regulation in the Russian Federation" of 08/03/2018. Customs clearance and other customs fees for goods placed under the export procedure that are not subject to export duties are canceled. Consequently, in the port of Ust-Luga, customs authorities do not charge a fee for their services with the products of LLC "Industrial Group "Phosphorite".

In addition, goods placed under the transit procedure are also exempt from customs duties, i.e. Customs clearance at Ivangorod border customs is not charged.

But Estonian customs authorities at the border section of Narva carry out customs inspection of transit cargo, for which a fee of 512 rubles / wagon is established.

4. Despite the fact that the port of Sillamae is located $10 \mathrm{~km}$ closer to the production of LLC "Industrial Group "Phosphorite", the time for delivery to this port is much longer, due to the need to cross state borders and the need to fulfill border, customs and other formalities.

5. Another important point when conducting export operations is the preparation of documentation for customs clearance. When conducting a transaction through the Estonian port of Sillamae, it is necessary to prepare two sets of documents: one for issuing transit through the territory of Estonia, and the second for making export from Estonia. And when conducting an export operation through the Russian port of Ust-Luga, it is necessary to prepare only a series of documents exclusively for customs clearance of the export of goods from Russia to the destination country. Accordingly, the time and money costs in the first case will be greater.

6. The turnaround time of the route also varies greatly depending on the selected port. So, for example, when moving to the port of Ust-Luga, the empty rolling stock will return 3 days after leaving the enterprise, which is 2 days faster than through the port of Sillamae. The shorter turnaround time of the route allows you to carry out more transactions with your own rolling stock at your disposal.

7. LLC "Industrial Group "Phosphorite" for transshipment of its products in ports uses the capacities of its own terminals built on leased land. Consequently, the placement of the terminal in the port of Ust-Luga will be cheaper by 200 thousand rubles / ha, which is associated with different rental rates in Estonia and Russia.

Following the data presented in table 2, we will calculate what costs for the delivery of 2275 tons of ammophos will be incurred by LLC "Industrial Group "Phosphorite" if two different ports are used. The resulting data will be listed in table 3 . 
Table 3. Comparison of the cost of delivery of cargo to the port of Sillamae and the port of Ust-Luga.

\begin{tabular}{|c|c|c|}
\hline Indicators & $\begin{array}{c}\text { Port of } \\
\text { Sillamae }\end{array}$ & Port of Ust-Luga \\
\hline $\begin{array}{c}\text { Shipping cost of loaded } \\
\text { composition, rubles }\end{array}$ & 473900 & 548800 \\
\hline Empty refund cost, rubles & 60900 & 52745 \\
\hline $\begin{array}{c}\text { Fee for transit of loaded train, } \\
\text { rubles }\end{array}$ & 539175 & - \\
\hline Empty transit fee, rubles & 56000 & - \\
\hline Customs inspection fee, rubles & 17920 & - \\
\hline Total, rubles & 1147895 & 601545 \\
\hline
\end{tabular}

Thus, the total cost of transporting ammophos weighing 2275 tons to the port of Sillamae is 1147895 rubles, while the delivery of the same mass to the port of Ust-Luga will cost 601545 rubles. This difference is due to the different number of boards that must be implemented during transportation.

Table 4. Comparison of the profitability of the transaction with the German AgroGer GmbH on the new and old conditions.

\begin{tabular}{|c|c|c|c|c|}
\hline Indicators & $\begin{array}{c}\text { Values } \\
\text { for old } \\
\text { conditio } \\
\text { ns }\end{array}$ & $\begin{array}{c}\text { Values for } \\
\text { new } \\
\text { conditions }\end{array}$ & $\begin{array}{c}\text { Deviatio } \\
\mathrm{n},+/-\end{array}$ & $\begin{array}{c}\text { Growth rate, } \\
\%\end{array}$ \\
\hline $\begin{array}{c}\text { The cost of exported goods, thousand } \\
\text { rubles }\end{array}$ & 59150 & 59150 & - & - \\
\hline VAT paid by suppliers, thousand rubles & 9464 & 9464 & - & - \\
\hline Overhead export costs, thousand rubles & 39600 & 29050 & -10550 & -27 \\
\hline $\begin{array}{c}\text { VAT, overhead export costs, thousand } \\
\text { rubles }\end{array}$ & 3960 & 2905 & -1055 & -27 \\
\hline Contract value, thousand rubles & 105360 & 96710 & -8650 & -8 \\
\hline Contract value, dollars & 1435,0 & 1317,2 & -118 & -8 \\
\hline $\begin{array}{c}\text { One-time income from the sale of } \\
\text { exported goods, thousand rubles }\end{array}$ & 6610 & 8510 & +1900 & +29 \\
\hline $\begin{array}{c}\text { Contingent income from the sale of } \\
\text { export goods, thousand rubles }\end{array}$ & 20034 & 20879 & +845 & +4 \\
\hline $\begin{array}{c}\text { Profitability of the transaction (one-time), } \\
\%\end{array}$ & 11,2 & 14,4 & +3 & +29 \\
\hline $\begin{array}{c}\text { Profitability of the transaction } \\
\text { (conditional), } \%\end{array}$ & 33,9 & 35,3 & +1 & +4 \\
\hline
\end{tabular}

Taking into account the proposed recommendations, an assessment was made of the economic efficiency of the new export operation with the German company AgroGer $\mathrm{GmbH}$. By comparing the results with the previously completed transaction indicated above by AgroGer GmbH, but through the Estonian port of Sillamae and DAT port of Hamburg, we can draw the following conclusions:

1. The cost of exported goods remained unchanged, since the same amount of ammophos was sold in the transactions under consideration, namely 2275 tons at a price of 26000 rubles / ton. VAT paid to suppliers also remained unchanged.

2. Overhead export costs for the new transaction will decrease 10,550 thousand rubles. Such a decrease will occur due to the fact that under the terms of the new transaction, the cargo will be sent through the Russian port of Ust-Luga, i.e. the company will avoid the need to pay Estonian transit in the amount of 1147.9 thousand rubles. In addition, if the terms of delivery on the CPT Ust-Luga change, LLC "Industrial Group "Phosphorite" will reduce the cost of export documentation, import customs payments, freight forwarding 
services, cargo insurance. As a result, the VAT on export overhead expenses will decrease by 1055 thousand rubles. and will amount to 2905 thousand rubles.

3. The contract value of the transaction under the new conditions will be 96710 thousand rubles, which is 8650 thousand rubles less than under the old conditions.

4. A non-recurring income, which is equal to the contract value minus the value of the export product and export overhead, will increase 1900 thousand rubles, or $29 \%$.

5. Based on paragraph 1 of Article 164 of the Tax Code of the Russian Federation, when exporting goods or services abroad, VAT equal to $0 \%$ is applied. Since this is not a full tax exemption, but only a reduction of the rate to $0 \%$, a company that is subject to the VAT rate has the right to a tax deduction, i.e. has the opportunity to present the amount of "input" VAT on raw materials, materials, goods, work and services related to the export, deductible. In this regard, the conditional income from the sale of exported goods was calculated, which shows how much profit the company will receive if it complies with all the rules for obtaining a tax deduction. Contingent income on a new transaction will be 20879 thousand rubles, which is 845 thousand rubles more than on the old transaction.

6. The one-time profitability of a new transaction with a German company, showing the effectiveness of the transaction without taking into account the profit received from the tax deduction, will increase from $11.2 \%$ to $14.4 \%$. Conditional profitability will also increase from $33.9 \%$ to $35.3 \%$.

\section{Conclusion}

Conducting export transactions through the port of Ust-Luga for the LLC "Industrial Group "Phosphorite" enterprise is the most effective. Since when delivering to a given port, an enterprise minimizes its cash and time costs. The enterprise of EuroChem Group AG should think about opening its own terminal in the port of Ust-Luga. Such a terminal will allow transshipment and storage of not only the products of LLC "Industrial Group "Phosphorite", but also EuroChem subsidiaries such as Novomoskovsky Nitrogen, the EuroChem-Usolsky Potash Plant and the ammonia plant in Kin-gisepp under construction. Accordingly, the efficiency of the export operations of these companies will be higher than when using the Estonian port of Sillamae.

\section{References}

1. T.V. Kirillova, Modern science: actual problems of theory and practice. Series: Economics and law No. 4, 62-67 (2016)

2. S.I., Golovkina, O.A. Shevchuk, K.S. Karpova, Actual problems of science and practice No. 1 (006), 13-16 (2017)

3. T.V. Kirillova, Collection of scientific articles of the 9th International scientific and practical conference, 180-183 (2019)

4. L.I. Trinka, Economic analysis: theory and practice; under the editorship of E.V. Lehman. JOB, 156 (2008)

5. N.A. Kozlova, S.I. Golovkina, I. Kudriavtsev, Proceedings of the 33rd International Business Information Management Association Conference, Education Excellence and Innovation Management through Vision 2020, 9523-9530 (2020)

6. Official site of the port of Sillamae https://ee.sputniknews.ru/economy/20180112/8796259/port-sillamjaje.html

7. Official site of the port of Vyborg (2020) https://www.pasp.ru/port_vyborg1

8. Official site of the port of Ust-Luga (2020) URL: www.ust-luga.ru/activity/port/ 
9. The official website of Russian Railways (2018) URL: http://doc.rzd.ru/doc/public/ru?STRUCTURE_ID=704\&layer

10. The official website of Russian Railways (2020) URL: http://doc.rzd.ru/doc/public/ru?STRUCTURE_ID=704\&layer_id

11. The official website of Russian Railways (2020) URL: http://doc.rzd.ru/doc/public/rufiles/tarifnaja_politika_2019.pdf 